\title{
Plasma Growth Hormone-Binding Protein Activity, Insulin-like Growth Factor I, and Its Binding Protein Levels in Patients with Turner's Syndrome: Effect of Short- and Long-Term Recombinant Human Growth Hormone Administration
}

\author{
GIUSEPPE SAGGESE, GIOVANNI FEDERICO, AND LUISA CINQUANTA
}

Chair of Preventive Paediatrics, Institute of Paediatrics, University of Pisa, Pisa, Italy

\section{ABSTRACT}

\begin{abstract}
Plasma growth hormone-binding protein (GH-BP) activity and the levels of IGF-I and its binding proteins (IGFBP) were studied in eight girls with Turner's syndrome before and during recombinanthGH (r-hGH) administration. Growth hormone and GH-BP activity were assayed at baseline and hourly, over a 12-h period, after an intramuscular bolus of $0.09 \mathrm{mg} / \mathrm{kg}$ of the hormone. After $7 \mathrm{~d}$, each patient received $\mathrm{r}$-hGH at $0.33 \mathrm{mg} / \mathrm{kg} /$ weekly s.c. every day at nighttime; plasma growth hormone-binding protein activity, blood IGF-I, and IGFBP were evaluated before and on d 7, 30, 180, and 360. Baseline reference values were obtained from 10 bone agematched healthy girls. Basal GH-BP activity, IGF-I, and IGFBP levels were similar in patients and controls. Four $\mathrm{h}$ after the intramuscular injection, GH-BP activity maximally increased and returned to baseline $6-7 \mathrm{~h}$ later; during long-term r-hGH administration GH-BP activity peaked at $+180 \mathrm{~d}$ but declined to pretreatment at +360 d. IGF-I, IGFBP-3, and IGFBP-4 increased under $\mathrm{r}-\mathrm{hGH}$
\end{abstract}

Short stature is one of the greatest problems for patients with Turner's syndrome either in childhood or adulthood. Recently, many trials with $\mathrm{r}$-hGH have shown that supraphysiologic doses of the hormone increase the height velocity of these girls (1-4), permitting them to grow beyond their genetic potential (5). However, the pathogenesis of the growth disorder remains to be elucidated so far. In fact, in these girls the GH secretory status has been found normal (6-9) or impaired, mostly after the bone age of $10 \mathrm{y}$ (6) or the chronologic age of $9 \mathrm{y}(10)$, when the growth delay is already manifest. In addition, the direct demonstration of an end-organ resistance to IGF-I has yet to be demonstrated, even if recent evidence supports this hypothesis (11).

Received January 2, 1994; accepted July 20, 1994

Correspondence: Giuseppe Saggese, M.D., Chair of Preventive Pediatrics, Institute of Pediatrics, University of Pisa, Via Roma 67, I-56125 Pisa, Italy.

Supported in part by grants from the Italian Ministry of Scientific Research. and, in contrast to GH-BP activity, remained high throughout the study. In conclusion, in girls with Turner's syndrome, GH-BP activity, IGF-I, IGFBP-3, and IGFBP-4 are induced by $\mathrm{r}-\mathrm{hGH}$. However, the increase of IGF-I and IGFBP-3 does not require an increased level of the cellular growth hormone receptors, as suggested by the unchanged $+360 \mathrm{~d}$ values of plasma GH-BP activity compared with baseline. The absence of an association among any of the biochemical parameters studied and the growth of the patients taking $\mathrm{r}$-hGH suggests that a peripheral defect may affect their growth. (Pediatr Res 37: 106-111, 1995)

\section{Abbreviations}

GH, growth hormone

GH-BP, growth hormone-binding proteins

IGFBP, IGF binding proteins

r-hGH, recombinant hGH
There is general agreement that GH and IGF-I circulate in the blood bound to specific proteins, GH-BP and IGFBP, respectively, which are at least involved in the regulation of growth processes by modulating the biologic activity of both hormones (12-14).

It is now thought that the circulating low-capacity, highaffinity GH-BP represents the extracellular region of the $\mathrm{hGH}$ receptor $(15,16)$, so that by assaying such a protein in the blood one would know the "receptor state" of the subject (17). In addition, it has been shown that the levels of this protein are up-regulated by $\mathrm{GH}(18,19)$. Few and conflicting data are available on the plasma GH-BP activity in girls with Turner's syndrome. Zadik et al. (11) found normal activity in an age range of 5.5-16.3 y, whereas Massa et al. (20) reported that $\mathrm{GH}-\mathrm{BP}$ activity was increased in overweight adolescent girls and was not influenced by $r-h G H$ administration (20). 
Regarding IGFBP, previous data showed that girls with Turner's syndrome have normal levels of IGFBP-1 (21) and -3 (the GH-dependent IGFBP) (22), the latter being inducible by short-term r-hGH administration (23).

In patients with Turner's syndrome, we studied the acute changes of the plasma GH-BP activity after the injection of $\mathrm{r}-\mathrm{hGH}$ and its behavior with that of IGF-I and IGFBP during long-term administration of the hormone. Our results show that 1) plasma GH-BP activity, IGF-I, and IGFBP are expressed in baseline conditions as in control girls; 2) plasma GH-BP activity is acutely induced by r-hGH administration; and 3) long-term $\mathrm{r}$-hGH treatment increases plasma GH-BP activity, IGF-I, IGFBP-3 and IGFBP-4 (the levels of the last three remained high throughout the study, whereas the first increased transiently).

\section{METHODS}

\section{Subjects}

We studied eight girls with Turner's syndrome (Table 1). None of the patients were overweight or had signs of puberty; GH secretion in response to two provocative tests was normal in all (maximal peaks of GH during insulin-induced hypoglycemia and after $x$-dopa administration were $14.6 \pm 2.0$ and $14.7 \pm 3.1 \mu \mathrm{g} / \mathrm{L}$, respectively). None of them were taking any hormonal drug when the study started and r-hGH was the only hormonal drug they received throughout the study. Blood samples from 10 bone age-matched healthy girls (Table 1) served as controls. The study protocol was approved by the ethical committee of our department, and in all cases parental consent accompanied that of the subjects.

\section{Study Protocol}

$r$-hGH-induced acute changes of plasma GH-BP activity. After a blood sample was obtained in basal condition for the evaluation of serum GH levels and plasma GH-BP activity, all girls received intramuscular injections with $0.09 \mathrm{mg} / \mathrm{kg}$ of r-hGH (Genotropin, Pharmacia, Stockholm, Sweden) followed by a hourly blood sampling over the next $12 \mathrm{~h}$.

Plasma GH-BP activity during long-term r-hGH administration. After a 7-d washout period, each patient underwent long-term $\mathrm{r}-\mathrm{hGH}$ administration of $0.33 \mathrm{mg} / \mathrm{kg} / \mathrm{wk}$ given s.c. every day at nighttime. Blood samples for IGF-I, plasma
GH-BP activity, and IGFBP determination were collected before and on $\mathrm{d} 7,30,180$, and 360 after the start of therapy.

Blood sampling was always performed after an overnight fast and no more than $12 \mathrm{~h}$ after the last $\mathrm{r}-\mathrm{hGH}$ administration. All samples were immediately aliquoted and stored at $-70^{\circ} \mathrm{C}$ until assayed.

\section{Methods}

Chemicals. Fresh radiolabeled ${ }^{125} \mathrm{I}-\mathrm{hGH}$ was obtained from Du Pont de Nemours Italiana SpA (Milan, Italy), and ${ }^{125}$ IIGF-I and ${ }^{14} \mathrm{C}$-labeled molecular weight markers were from Amersham Italia Srl (Milan, Italy). Dextran T-70 was purchased from Pharmacia-LKB (Uppsala, Sweden); BSA and Norit-A charcoal were obtained from Sigma Chemical Co. (St. Louis, MO); and ultrapure acrylamide, bis-acrylamide, $\mathrm{N}, \mathrm{N}, \mathrm{N}^{\prime}, \mathrm{N}^{\prime}$-tetramethylenediamine, persulfate, and SDS were from ICN-Flow Biomedicals, Inc. (Costa Mesa, CA). All other chemicals were of analytical grade and purchased from local commercial sources.

Plasma GH-BP activity assay. The activity assay was measured as the activity of plasma to bind ${ }^{125} \mathrm{I}-\mathrm{GH}$ using the $\mathrm{GH}$ binding assay based on dextran-coated charcoal separation described by Amit et al. (24). The specific ${ }^{125} \mathrm{I}-\mathrm{hGH}$ binding $/ 50 \mu \mathrm{L}$ plasma was calculated and expressed as a percentage of the total ${ }^{125} \mathrm{I}-\mathrm{hGH}$ incubated. In samples in which hGH levels were $>7 \mu \mathrm{g} / \mathrm{L}$, the results were corrected according to the ability of endogenous hormone to reduce the binding of ${ }^{125} \mathrm{I}-\mathrm{hGH}$ to human plasma.

Plasma GH-BP activity found in baseline condition and during the long-term therapy was compared with that of a reference adult pool ( ${ }^{125} \mathrm{I}$-hGH specific binding $=12.3 \pm$ $0.25 \%$ ) included in each assay and expressed as a percentage (percentage relative specific binding) (25). All samples from a single individual were run in the same assay, in triplicate. The intra- and interassay coefficients of variation of the assay were 1.43 and $4.72 \%$, respectively.

Analysis of IGFBP by ligand blotting. The method of Hossenlopp et al. (26) was used. Serum samples of $1.5 \mu \mathrm{L}$ were electrophoresed for $90 \mathrm{~min}$ at $30 \mathrm{~mA}$ on an SDS/12.5\% polyacrylamide minislab gel $(90 \times 70 \times 0.75 \mathrm{~cm}$ ) (Midget Electrophoresis Unit, Pharmacia-LKB) under nonreducing conditions (except in the case of the ${ }^{14} \mathrm{C}$-labeled molecular weight markers). Each set of samples, obtained from a single

Table 1. Clinical details of girls with Turner's syndrome

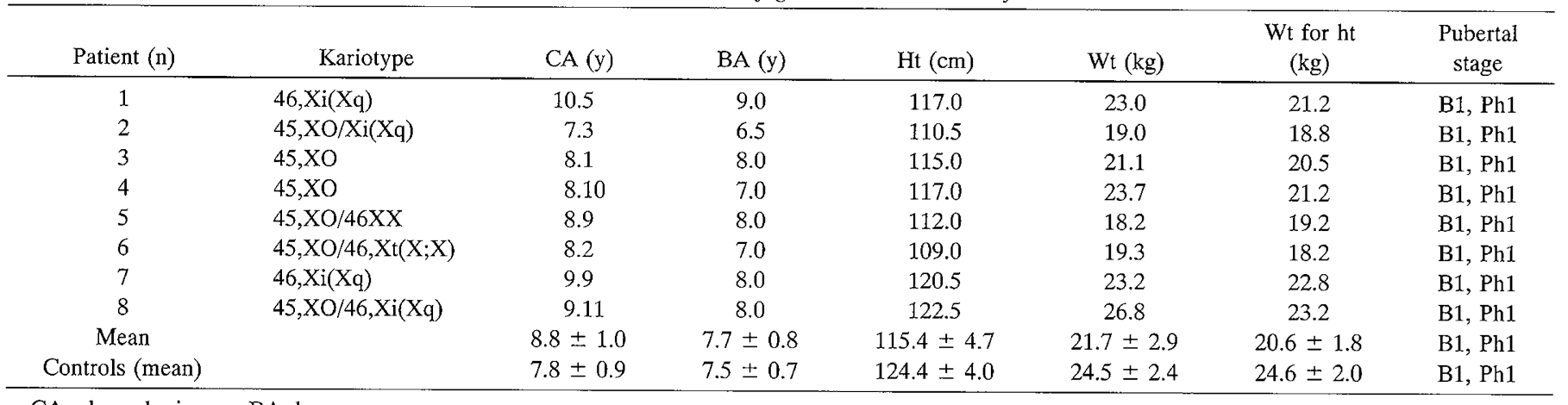

$\mathrm{CA}$, chronologic age; $\mathrm{BA}$, bone age. 
individual during the entire study period, was run on two different gels in the same apparatus. Proteins were electroblotted onto nitrocellulose membranes (Midget Multiblot Electrophoretic Transfer Unit) for $2 \mathrm{~h}$ at $300 \mathrm{~mA}$. Then the membranes were incubated in sealed bags with $400000 \mathrm{cpm}$ of ${ }^{125} \mathrm{I}$-IGF-I overnight at $4^{\circ} \mathrm{C}$. At the end of the incubation period, both membranes were exposed for $48 \mathrm{~h}$ at $-70^{\circ} \mathrm{C}$ to the same x-ray film (X-Omat AR, Eastman Kodak Co., Rochester, NY) in a Kodak X-Omatic cassette (Eastman Kodak Co.) with two intensifying screens. Autoradiograms were subjected to densitometric scanning (Pharmacia-LKB), and for each of the IGFBP species, comparisons were made on the basis of the intensity (absorbance units $\times \mathrm{mm}$ ) of the bands on parallel lanes of a single autoradiogram. Results are expressed as a percentage of a reference pool of sera, obtained from pubertal healthy girls, run in the same autoradiogram.

$\boldsymbol{h} \boldsymbol{G H}$ and IGF-I assay. hGH serum levels were assayed using a coated tube RIA kit (hGH Spectria kit, Orion Corporation, Farmos, Turku, Finland). The minimum detectable level was $0.2 \mu \mathrm{g} / \mathrm{L}$, and the intra- and interassay coefficients of variation were 6.55 and $9.74 \%$, respectively.

Plasma IGF-I values were determined using a commercial kit (Nichols Institute Diagnostics, San Juan Capistrano, CA) that encloses an acid chromatography extraction step on small prepacked silica columns (C-18 Sep-pak, Millipore, Waters Associates, Bedford, MA). Each sample was assayed in duplicate. The sensitivity of the method was $0.06 \mu \mathrm{g} / \mathrm{L}$ and the intraand interassay coefficients of variation were 2.85 and $10.21 \%$, respectively.

\section{Statistical Analysis}

Results are expressed as mean $\pm \mathrm{SD}$. Comparisons between the mean data from patients in baseline conditions and control subjects were made by one-way analysis of variance, followed by the Bonferroni least significant difference test to identify which groups were significantly different. The effect of r-hGH administration was evaluated by multiple measures analysis of variance, followed by the Bonferroni least significant difference test. The association among the various parameters examined was calculated by regression analysis. $p<0.05$ was considered significant.

\section{RESULTS}

Plasma GH-BP activity after acute or long-term r-hGH administration. Baseline plasma GH-BP activity was not different between patients and controls (cumulative data obtained before acute and long-term $\mathrm{r}-\mathrm{hGH}=60.3 \pm 5.1 \%$ versus 63.8 $\pm 6.4 \%$ specific relative binding, respectively; $p=\mathrm{NS}$ ). Acute r-hGH-induced changes of plasma GH-BP activity are shown in Figure 1. GH serum levels increased sharply after injection reaching a "plateau" and progressively fell toward baseline. GH-BP activity began to increase, even if not significantly, $3 \mathrm{~h}$ after r-hGH injection, reached the maximal elevation between 4 and $5 \mathrm{~h}$, and declined subsequently into the baseline levels.

Table 2 shows the r-hGH-induced changes of plasma GH-BP activity during the long-term administration of the hormone. Baseline activity increased during r-hGH adminis-

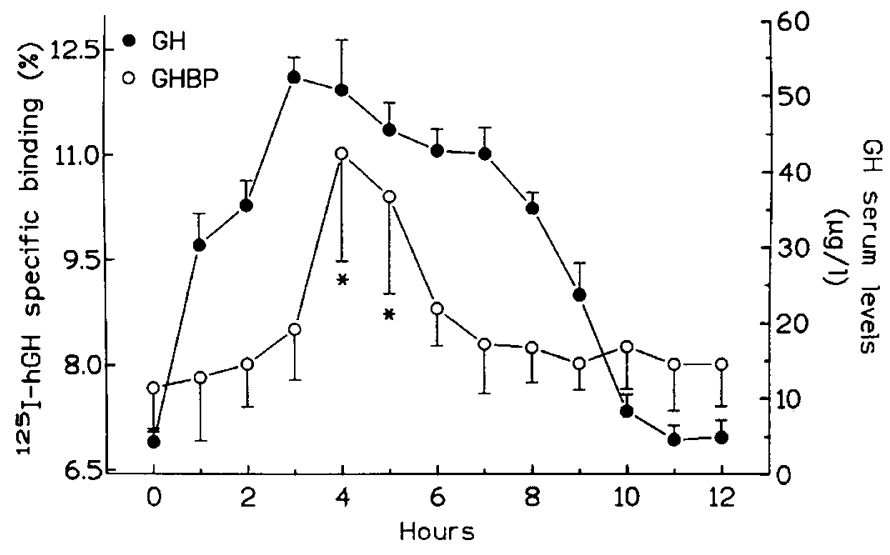

Figure 1. Acute changes of $\mathrm{GH}$ and $\mathrm{GH}-\mathrm{BP}$ after $0.09 \mathrm{mg} / \mathrm{kg}$ of r-hGH injected intramuscularly. ${ }^{*}, p<0.001 v s 0$.

tration reaching the maximum value at $+180 \mathrm{~d}$ but returned close to the pretreatment levels thereafter. Before $\mathrm{r}-\mathrm{hGH}$ administration, Scatchard analysis showed an average affinity constant of $1.1 \pm 0.1 \times 10^{9} \mathrm{~L} / \mathrm{mol}$ with a binding capacity of $516 \pm 5.27 \mathrm{fmol} / \mathrm{mL}$ of plasma. At $+180 \mathrm{~d}$, affinity constant was unchanged $\left(1.14 \pm 0.1 \times 10^{9} \mathrm{~L} / \mathrm{mol} ; p=\mathrm{NS}\right)$ although the binding capacity was significantly increased over baseline $(648 \pm 33.5 ; p<0.0001)$, indicating that the augmented plasma GH-BP activity was related to an increased binding capacity rather than to a change of affinity (Fig. 2).

\section{IGF-I and IGFBP Changes during r-hGH Therapy}

Baseline IGF-I plasma levels were not different in girls with Turner's syndrome compared with control subjects (153.0 \pm 12.7 versus $168.0 \pm 27.5 \mu \mathrm{g} / \mathrm{L}$, respectively; $p=\mathrm{NS}$ ). Furthermore, $\mathrm{r}-\mathrm{hGH}$ administration increased IGF-I levels that reached the "plateau" after $30 \mathrm{~d}$ (Table 2).

The ligand blotting for IGFBP showed five bands: a doublet and three fainter bands (Fig. 3). When compared with the migration of the ${ }^{14} \mathrm{C}$ molecular weight markers, the $\mathrm{M}_{\mathrm{r}}$ of the

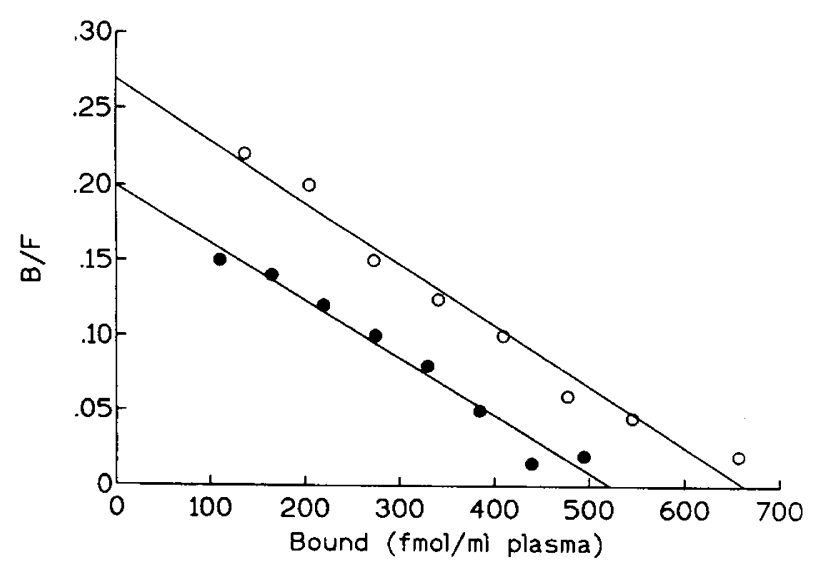

Figure 2. Representative Scatchard analysis of ${ }^{125} \mathrm{I}-\mathrm{GH}$ binding to a plasma sample obtained from a girl with Turner's syndrome at baseline () and +180 $\mathrm{d}(\mathrm{O})$ of $\mathrm{r}-\mathrm{hGH}$ administration. The ordinate represents the ratio of bound/free hGH $(B / F)$, and the abscissa the fmol bound per $\mathrm{mL}$ of plasma. At the start of $\mathrm{r}-\mathrm{hGH}$ administration, the binding capacity was $523.1 \mathrm{fmol} / \mathrm{mL}$ with a $\mathrm{Ka}$ of $1.15 \times 10^{9} \mathrm{~L} / \mathrm{mol}$; at $+180 \mathrm{~d}$ the binding capacity increased to $663.4 \mathrm{fmol} / \mathrm{mL}$ whereas the affinity constant remained substantially unchanged $\left(0.93 \times 10^{9}\right.$ $\mathrm{L} / \mathrm{mol})$. 


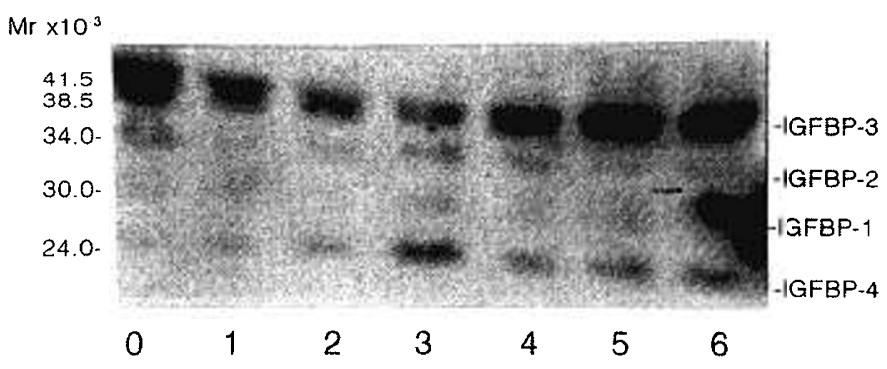

Figure 3. Representative autoradiogram showing the pattern of serum IGFBP in a girl with Turner's syndrome before (lane 2) and during long-term r-hGH administration (lanes 3-6) as described in the text. Lanes 1 and 0 are from the bone age-matched control girl and from the reference pool, respectively. There is a clear-cut increase of IGFBP-3 and -4-related bands in the patient under $\mathrm{r}$-hGH therapy.

bands were $41500,38500,34000,30000$, and 24000 , respectively, similar to the migratory pattern of human IGFBP-3, $-2,-1$, and -4 previously described in human serum (24). Figure 3 is a representative autoradiogram showing the pattern of IGFBP of the reference pool, the pattern of a girl with Turner's syndrome before and during $\mathrm{r}-\mathrm{hGH}$ treatment, and the pattern of her bone age-matched control. Densitometric quantitation of IGFBP-3-related bands was not different in patients and controls before r-hGH $(45.4 \pm 7.3$ versus $51.2 \pm 9.4 \%$, respectively; $p=\mathrm{NS}$ ); rather, the bands progressively increased under hormonal therapy, reaching the maximal elevation after $180 \mathrm{~d}$, without appreciable changes thereafter (Table 2).

Also baseline IGFBP-4-related bands did not differ in patients compared with controls (100.9 \pm 19.1 versus $96.8 \pm$ $20.5 \%$ of the reference pool, respectively; $p=\mathrm{NS}$ ); under $\mathrm{r}-\mathrm{hGH}$ administration they increased up to $+151.2 \pm 24.7 \%$ over baseline $(p<0.001)$ on $\mathrm{d}+7$ without changing greatly thereafter $(+30 \mathrm{~d}=+163.2 \pm 32.8 \% ;+180 \mathrm{~d}=+148.9 \pm$ $11.0 \%$; $+360 \mathrm{~d}=+157.5 \pm 18.0 \%$ ).

With IGFBP-2 and -1, we did not find differences in patients compared with controls, and they did not vary significantly during the hormonal therapy (data not shown).

\section{Effect of Long-Term r-hGH on Growth}

After $360 \mathrm{~d}$ of $\mathrm{r}$-hGH therapy, the height velocity of the patients increased from $3.23 \pm 0.68$ to $6.41 \pm 1.09 \mathrm{~cm} / \mathrm{y}(p<$ 0.0001 ) with a $\Delta$ increment of $101.4 \pm 25.8 \%$. Regression analysis showed that there were no correlations among plasma
GH-BP activity, IGF-I, and IGFBP levels either before or after acute or long-term $\mathrm{r}-\mathrm{hGH}$ and the growth of the patients evaluated as height velocity $(\mathrm{cm} / \mathrm{y})$ or the $\Delta$-increment height velocity at 6 or 12 mo of therapy.

\section{DISCUSSION}

Our results confirm that normal weight, prepubertal-aged girls with Turner's syndrome have normal baseline plasma GH-BP activity, IGF-I levels, and IGFBP-3 levels, as previously reported $(11,6,27)$. In addition we have also shown that IGFBP -4 values are similar in patients and controls.

$\mathrm{r}-\mathrm{hGH}$ administration showed that plasma GH-BP activity is acutely inducible by the hormone $(+52 \%$ mean maximal increase over baseline; Fig. 1) as found by Zadik et al. (28) in normal subjects $(+30 \%)$. Moreover, the $\mathrm{r}-\mathrm{hGH}-$ induced in crease of plasma GH-BP activity during long-term administration was transient, as indicated by the dropoff observed at $+360 \mathrm{~d}$ (Table 2). That unexpected event may be due to the failure of the long-term exposure to supraphysiologic doses of the hormone to sustain the up-regulation of the hGH receptor; a similar mechanism seems involved in patients with acromegaly (29), in whom elevated GH levels and low GH-BP activity coexist, suggesting a down-regulation of the $\mathrm{GH}$ receptor due to the long-lasting high $\mathrm{GH}$ levels (27). Others did not observe significant variations of plasma GH-BP activity in long-term r-hGH-treated Turner patients (20); it should be noted that the study involved adolescent girls in whom, due to overweight $(29,30)$, the baseline levels of GH-BP were higher than those found in either bone age- or chronologic age-matched controls.

Under r-hGH administration, IGF-I levels increased more than 2-fold over baseline, reaching values attained, between the stages $\mathrm{B} 2, \mathrm{Ph} 2$ and $\mathrm{B} 3, \mathrm{Ph} 3$ (31), by normal girls at puberty; thus, r-hGH therapy brought IGF-I into levels above physiologic development if compared with the auxologic development of our patients. In addition, IGF-I remained high during long-term r-hGH administration $(20,32)$, and it was not influenced by the fall of plasma GH-BP activity observed at $+360 \mathrm{~d}$.

As expected from short-term trials with $\mathrm{r}$-hGH $(23,33)$, IGFBP-3 levels significantly rose during long-term administration of the hormone (Fig. 3) and remained high throughout the study period, paralleling the behavior of IGF-I. Thus, even if between +180 and +360 d plasma GH-BP activity dropped

Table 2. Plasma GH-binding activity, IGF-I, and IGFBP-3 levels in Turner patients before and during $r$-hGH

\begin{tabular}{cccccc}
\hline & Baseline & +7 & +30 & +180 & +360 \\
\hline GH-BP* $(\%)$ & $58.4 \pm 4.2$ & $59.1 \pm 5.1$ & $66.6 \pm 3.4 \dagger$ & $77.8 \pm 6.9 \neq$ & $60.5 \pm 3.2$ \\
IGF-I $(\mu \mathrm{g} / \mathrm{L})$ & $153.0 \pm 12.7$ & $188.1 \pm 10.2 \S$ & $367.4 \pm 32.2$ & $383.6 \pm 24.9$ & $401.3 \pm 22.3$ \\
IGFBP-3 $(\%)$ & $45.3 \pm 6.3$ & $54.5 \pm 7.1^{* *}$ & $82.4 \pm 9.4$ & $98.2 \pm 11.3+\dagger$ & $96.3 \pm 8.6$ \\
\hline
\end{tabular}

* GH-BP, plasma GH-binding activity expressed as \% relative specific binding.

$\dagger p<0.05$ vs 0 .

$\ddagger p<0.001$ vs 0 and +360 , and $p<0.01$ vs +30

$\S p<0.05 v s 0$.

$\| p<0.001$ vs 0 and +7 .

** $p<0.01$ vs 0 .

†† $p<0.001$ vs $0,+7$, and +30 . 
into the pretreatment values, it appeared that the level of the expression of the cellular receptor for $\mathrm{GH}$ was enough to guarantee the response to the hormone.

Long-term $\mathrm{r}-\mathrm{hGH}$ administration significantly increased the growth of our patients. However, we did not find any association among hormonal and growth data. In contrast to Martha et al. (34), who found that in GH-deficient children pretreatment GH-BP levels were highly correlated with the growth velocity at 12 mo of $\mathrm{r}-\mathrm{hGH}$, we failed to observe such a correlation in our patients. Taken together, our data suggest that GH-BP levels may not be a predictor of the response to GH therapy in Turner's syndrome, as proposed for GH deficiency (34), and that a peripheral defect, such as an end-organ resistance to IGF-I (11), may be in part responsible for their impaired growth.

r-hGH induced also IGFBP-4, a protein released by a number of human cell types, including chondrocytes of the growing cartilage (35) and osteoblasts $(35,36)$, which exerts in vitro an inhibitory effect on the IGF-I actions at cellular levels (36). Our data do not allow us to establish the net effect of the increased levels of this protein on the growth of girls with Turner's syndrome under r-hGH. Inasmuch as these patients grow better under supraphysiologic $\mathrm{r}-\mathrm{hGH}$ (5), it may be that the increased IGFBP-4 levels reflect an adaptive mechanism that, by modulating IGF action, balances the strong stimulatory action on cellular growth triggered by exogenous $\mathrm{r}-\mathrm{hGH}$.

The increased levels of IGFBP-3 and -4 may reflect a decrease of the activity of specific proteases (37-39), an enhanced synthesis, or both. Because we did not measure these activities, we cannot directly address the question. Some observations indicate that protease activity is increased when IGF-I levels are decreased (40); thus, a possible IGF-I-induced decrease of protease activity in our long-term treated patients cannot be ruled out.

In conclusion, in young, normal weight girls with Turner's syndrome, plasma GH-BP activity may be inducible by r-hGH as well as IGF-I and, among IGFBP, IGFBP-3 and -4. However, if the assumption that plasma $\mathrm{GH}-\mathrm{BP}$ activity reflects the level of the expression of $\mathrm{GH}$ receptors is correct, then the increase of IGF-I and IGFBP-3 levels does not require an increased level of the cellular GH receptors, as suggested by the unchanged $+360 \mathrm{~d}$ values of plasma GH-BP activity, compared with baseline. The absence of an association among any of the biochemical parameters studied (plasma GH-BP activity, IGF-I levels, and IGFBP levels) and the growth of the patients under $\mathrm{r}$-hGH suggests that a peripheral defect, such as a resistance to IGF-I, may participate in causing the growth failure. Additional studies are needed to ascertain, in girls with Turner's syndrome, the relationships among chondrocytes of the growth plate and GH, IGF-I and its receptor, and the IGF-I/IGFBP complex.

\section{REFERENCES}

1. Rosenfeld RG, Hinz RL, Johanson AJ 1986 Methionyl human growth hormone and oxandrolone in Turner's syndrome: preliminary results of a prospective randomized trial. J Pediatr 109:936-943

2. Takano K, Hizuka N, Shizume K 1986 Growth hormone treatment in Turner's syndrome. Acta Paediatr Scand Suppl 325:58-63
3. Rongen-Westerlaken C, Witt JM, Drop SLS 1988 Methionyl human growth hormone in Turner's syndrome. Arch Dis Child 63:1211-1217

4. Vanderschueren-Lodeweyckx M, Massa G, Maes M 1990 Growth-promoting effect of growth hormone and low-dose ethinyl estradiol in girls with Turner's syndrome. J Clin Endocrinol Metab 70:122-126

5. Rosenfeld RG 1992 Growth hormone therapy in Turner's syndrome: an update on final height. Acta Paediatr Scand Suppl 383:3-6

6. Ranke MB, Blum VF, Haug F, Rosendahl W, Attanasio A, Enders H, Gugpta D, Bierich JR 1987 Growth hormone, somatomedin levels and growth regulation in Turner's syndrome. Acta Endocrinol 116:305-313

7. Lanes R, Brito S, Suniaga M, Moncada G, Borges M 1990 Growth hormone secretion in pubertal age patients with Turner's syndrome. J Clin Endocrinol Metab 71:770772

8. Van Es A, Massarano AA, Wit JM, Hindmarsh PC, Kamp GA, Brook CJD, Preece MA, Matthews DR 1991 24-hour growth hormone secretion in Turner syndrome. In: Ranke MB, Rosenfeld RG (eds) Turner Syndrome: Growth Promoting Therapy. Excerpta Medica, Amsterdam, pp 29-33

9. Albertsson-Wikland K, Rosberg S 1991 Pattern of spontaneous growth hormone secretion in Turner syndrome. In: Ranke MB, Rosenfeld RG (eds) Turner Syndrome: Growth Promoting Therapy. Excerpta Medica, Amsterdam, pp 23-28

10. Ross JL, Long LM, Loriaux DL, Cutler Jr GB 1985 Growth hormone secretory dynamics in Turner syndrome. J Pediatr 106:202-206

11. Zadik Z, Landau H, Chen M, Altman Y, Lieberman E 1992 Assessment of growth hormone $(\mathrm{GH})$ axis in Turner's syndrome using 24-hour integrated concentrations of $\mathrm{GH}$, insulin-like growth factor-1, plasma GH-binding activity, GH binding to IM9 cells, and GH response to pharmacological stimulation. J Clin Endocrinol Metab 75:412-416

12. Baumann G, Stolar MW, Amburn K, Barsano CP, Devries BC 1976 A specific growth hormone binding protein in human plasma: initial characterization. J Clin Endocrinol Metab 62:134-141

13. Baxter RC, Martin JL 1989 Binding proteins for the insulin-like growth factor: structure, regulation and function. Prog Growth Factor Res 1:49-68

14. Rosenfeld RG, Lamson G, Pham H, Oh Y, Conover C, De Leon DD, Donovan SM, Ocrant I, Giudice L 1990 Insulin-like growth factor binding proteins. Recent Prog Hormone Res 46:99-163

15. Leung DW, Spencer SA, Cachianes G 1987 Growth hormone receptor and serum binding protein: purification, cloning and expression. Nature 330:537-543

16. Baumann $G$, Shaw MA 1988 Immunochemical similarity of the human plasma growth hormone-binding protein and the rabbit liver growth hormone receptor. Biochem Biophys Res Commun 152:573-578

17. Baumann G, Shaw MA, Amburn CK 1988 A rapid and simple assay for growth hormone-binding protein activity in human plasma. Acta Endocrinol 119:529-534

18. Postel-Vinay MC, Tar A, Hocquette JF, Clot JP, Fontoura M, Brauner R, Rappaport R 1991 Human plasma growth hormone (GH)-binding proteins are regulated by $\mathrm{GH}$ and testosterone. J Clin Endocrinol Metab 73:197-202

19. Hochberg Z, Barkey RJ, Even L, Peleg I, Youdim MBH, Amit T 1991 The effect of human growth hormone therapy on GH binding protein in GH-deficient children Acta Endocrinol (Copenh) 125:23-27

20. Massa G, Bouillon R, Vanderschueren-Lodeweyckx M 1992 Serum growth hormone (GH)-binding protein and insulin-like growth factor-1 levels in Turner's syndrome before and during treatment with recombinant human $\mathrm{GH}$ and ethinyl estradiol. J Clin Endocrinol Metab 75:1298-1302

21. Cianfarani S, Holly JM, Pasquino AM, Vaccaro F, Spadoni GL, Bernardini S, Segni M, Boscherini B 1992 Insulin-like growth factor binding protein 1 (IGFBP-1) levels in Turner syndrome. Horm Metab Res 24:537-540

22. Blum WF, Ranke MB 1990 Use of insulin-like growth factor-binding protein 3 for the evaluation of growth disorders. Horm Res 33(suppl 4):31-37

23. Van Teunenbroek A, De Muinck Kaizer-Schrama S, Stijnen T, Mouton JW, Blum WF, Mercado M, Baumann G, Drop SL 1993 Effect of growth hormone administration frequency on 24-hour growth hormone profiles and levels of other growth related parameters in girls with Turner's syndrome. Dutch Working Group on Growth Hormone. Clin Endocrinol (Oxf) 39:77-84

24. Amit T, Barkey RJ, Youdim MBH, Hochberg Z 1990 A new and convenient assay for growth hormone-binding protein activity in human serum. J Clin Endocrinol Metab 71:474-479

25. Daughaday WH, Trivedi B, Andrews BA 1987 The ontogeny of serum GH binding protein in men: a possible indicator of hepatic $\mathrm{GH}$ receptor development. J Clin Endocr Metab 65:1072-1074

26. Hossenlopp P, Seurin D, Segovia-Quinson B, Hardouin S, Binoux M 1986 Analysis of serum insulin-like growth factor binding proteins using Western blotting: use of the method for titration of the binding proteins and competitive binding studies. Anal Biochem 154:138-143

27. Blum WF, Ranke MB 1990 Use of insulin-like growth factor-binding protein-3 for the evaluation of growth disorders. Horm Res 33(suppl 4):31-37

28. Zadik Z, Ammon Z, Altman Y, Chen M 1993 The effect of exogenous and endogenous growth hormone on plasma growth hormone binding activity in prepubertal children. Horm Res 40:161-167

29. Baumann G, Shaw M, Amburn K 1989 Regulation of plasma growth hormone binding proteins in health and disease. Metabolism 38:683-689

30. Massa G, de Zegher F, Vanderschueren-Lodeweyckx M 1992 Serum growth hormone-binding protein in the human fetus and infant. Pediatr Res 32:69-72

31. Massa G, Bouillon R, Vanderschueren-Lodeweyckx M 1992 Serum levels of growth hormone-binding protein and insulin-like growth factor-1 during puberty. Clin Endocrinol 37:175-180 
32. Takano K, Shizume K, Hibi I and the members of the committee for the treatment of Turner's syndrome 1992 Treatment of 46 patients with Turner's syndrome with recombinant human growth hormone (YM-17798) for three years: a multicenter study. Acta Endocrinol 126:296-302

33. Willegerodt H, Keller E, Zeisel HJ, Stach B, Junghans P, Jung K, Willegerodt J, Blum WF 1991 The influence of treatment with rh-GH and oxandrolone on procollagen III peptide and protein metabolism, studied by means of $15 \mathrm{~N}$ tracer kinetics, in girls with Turner syndrome. In: Ranke MB, Rosenfeld RG (eds) Turner Syndrome: Growth Promoting Therapy. Excerpta Medica, Amsterdam, pp 145-150

34. Martha PM, Reiter EO, Davila N, Shaw MA, Holcombe JH, Baumann G 1992 Serum growth hormone $(\mathrm{GH})$-binding protein/receptor: an important determinant of $\mathrm{GH}$ responsiveness. J Clin Endocrinol 75:1464-1469

35. Federico G, Cinquanta L, Saggese G 1993 Effetti in vitro del GH ed altri ormoni sui condrociti e sugli osteoblasti. Ital J Pediatr 19(suppl 4):30(abstr)

36. Mohan S, Bautista CM, Wergedal J, Baylink DJ 1989 Isolation of an inhibitory insulin-like growth factor (IGF) binding protein from bone cell-conditioned medium: a potential local regulator of IGF action. Proc Natl Acad Sci USA 86: $8338-8342$

37. Hossenlop P, Segovia B, Lasarre C, Roghani M, Bredon M, Binoux M 1990 Evidence of enzymatic degradation of insulin-like growth factor-binding proteins in the $150 \mathrm{~K}$ complex during pregnancy. J Clin Endocrinol Metab 71:797-805

38. Giudice LC, Farrell EM, Pham H, Lamson G, Rosenfeld RG 1990 Insulin-like growth factor binding proteins in maternal serum throughout gestation and in the puerperium: effects of a pregnancy-associated serum protease activity. J Clin Endocrinol Metab $71: 806-816$

39. Kanzaki S, Hilliker S, Baylink D, Mohan S 1994 Evidence that human bone cells in culture produce insulin-like growth factor-binding protein- 4 and -5 proteases. Endocrinology 134:383-392

40. Holly MP, Claffey DCP, Cwyfan-Hughes SC, Frost VJ, Yateman ME 1993 Proteases acting on IGFBPs: their occurrence and physiological significance. Growth Regul 3:88-91 